Article

\title{
WOOD SUPPLY OPTIMIZATION IN BRAZILIAN PULP INDUSTRY INVOLVING FORESTRY OUTGROWER SCHEME
}

Matheus Andrade Ferreira ${ }^{2 *} \odot$, Carolina Souza Jarochinski e Silva ${ }^{3} \odot$, Lucas Rezende Gomide ${ }^{3} \odot$, Marco Antonio Contreras ${ }^{4} \odot$,Ezio Tadeu Lopes $^{5} \odot$, Rafael Carvalho Rodrigues ${ }^{6} \odot$,José Márcio de Mello $^{3} \odot$ and Nathalia de Paiva Mendonça ${ }^{2}$

${ }^{1}$ Received on 01.04.2019 accepted for publication on 30.08.2019.

${ }^{2}$ Suzano Papel e Celulose, Aracuz, ES - Brasil. E-mail: <matheusandrade.bs@gmail.com>and <nathalia.p.mendonca@hotmail.com>.

${ }^{3}$ Universidade Federal de Lavras, Departamento de Engenharia Florestal, Lavras, MG - Brasil. E-mail: <carolsjs@gmail.com> $<$ lucasgomide@ufla.br> and <josemarcio@dcf.ufla.br>.

${ }^{4}$ Universidad Austral de Chile, Instituto de Bosques y Sociedad, Facultad de Ciencias Forestales y Recursos Naturales, Valdivia, Chile. E-mail: <marco.contreras@uach.cl>.

${ }^{5}$ Universidade de Brasília, Departamento de Engenharia Florestal, Brasília, DF - Brasil. E-mail: <ezio.lopes@uol.com.br>.

${ }^{6}$ Universidade Federal de Viçosa, Departamento de Engenharia Florestal, Viçosa, MG - Brasil. E-mail: <rcrvix@hotmail.com>.

*Corresponding author.

\begin{abstract}
The objective of this study was to identify the best regions for allocation of a forestry outgrower scheme, and the most efficient transportation system, using a mathematical programming model to minimize the wood supply costs in three Brazilian states. The forest outgrower scheme is a partnership between producers and forest companies, without land acquisition by the companies. Forest producers are recognized as an important source of growth for forest production. In order to achieve successful partnerships, the company needs to plan its hiring. In this study, the partnerships are made through formal contracts and the model does not allow breach of contract. Six scenarios were modeled and evaluated based on the total cost of the objective function, average wood cost $\left(\mathrm{USD} / \mathrm{m}^{3}\right)$, average transport distance $(\mathrm{km})$ and processing time. The mathematical model showed its efficiency, effectiveness, and flexibility in generating scenarios to support company managers in the decision-making and to avoid breach of contract. Hiring planning benefits both sides as it ensures the company's production and provides financial security to forest producers. In addition, the model suggests alternatives such as the differential pricing of wood according to the location of the regions and the formation of homogeneous blocks of contracting/renewal of outgrower schemes around the pulp mill.
\end{abstract}

Keywords: Tactical Planning; Linear Programming; Forest Outgrower Scheme

\section{OTIMIZAÇÃO DO SUPRIMENTO DE MADEIRA NA INDÚSTRIA DE CELULOSE BRASILEIRA ENVOLVENDO FOMENTOS FLORESTAIS}

RESUMO - O objetivo deste estudo foi identificar as melhores regiões para alocação de fomentos florestais e sistemas de transporte mais eficientes, utilizando um modelo de programação matemática, para minimizar os custos de suprimento de madeira em três estados brasileiros. O fomento florestal é uma parceria entre produtores e empresas florestais, sem aquisição de terra por parte das empresas. Os produtores florestais são reconhecidos como uma importante fonte de plantio para a produção florestal. Para planejar parcerias bem-sucedidas, a empresa precisa planejar suas contratações. No presente estudo, foi considerado que as parcerias são realizadas por meio de contratos formais e que esse modelo de contratação não permite a quebra de contrato. Seis cenários foram modelados e avaliados com base no custo total da função objetivo, custo médio da madeira (USD $/ \mathrm{m}^{3}$ ), distância média de transporte $(\mathrm{km})$ e tempo de processamento. O modelo matemático mostrou sua eficiência, efetividade e flexibilidade na geração de cenários para apoiar os gestores da empresa nas tomadas de decisões e evitar quebras de contrato. O planejamento da contratação beneficia ambos os lados, pois garante a produção da empresa e fornece segurança financeira aos produtores florestais. Além disso, o modelo sugere alternativas como 
o preço da madeira diferenciado de acordo com a localização das regiões e a formação de blocos homogêneos de contratação/renovação de fomentos no entorno da fábrica de celulose.

Palavras-Chave: Planejamento tático; Programação linear, Fomento Florestal.

\section{INTRODUCTION}

In the last several decades, the expansion of agribusinesses in Brazil has caused a greater land appreciation, making agribusiness development unfeasible in areas of high population density. This competitive environment of land use has increased interest in the forest outgrower scheme. This scheme is a partnership between tree growers and forest companies, without land acquisition by companies, that promotes alternative income for small and medium-sized landowners (Rode et al., 2014).

According to Oliveira et al. (2006) and Rezende et al. (2006), outgrower schemes are a feasible option to increase the production of raw material because capital mobilization by forest companies is not required for land purchase, making possible smaller short-term investments. Meanwhile, advantages for outgrowers are the guaranteed sale of wood, technical assistance, and financial assistance with credits and readjustments (Rezende et al., 2006; Silva et al., 2009). Fischer and Zylbersztajn (2012) argued that wood originating from outgrower schemes plays a major role in the Brazilian pulp industry, occupying the second place in the matrix of raw material in longterm contracts.

Nonetheless, given the large distances between forest stands and the mills, the demand for wood requires an efficient logistical structure to reduce operational costs. Because Brazil is large and encompasses diverse environments, it has a diverse transportation system with $52 \%$ being roads, $30 \%$ rail, $8 \%$ seaway, $5 \%$ waterways, and $5 \%$ pipelines. In the Brazilian states of Espírito Santo, southern Bahia and northeastern Minas Gerais, there are three available modes of transportation (road, maritime and rail), which is different from most of the country where road transportation is the predominant system. This makes forest optimization more complex due to the large number of variables involved in the process such as distance between forest and mills, transportation systems, and the costs of maintenance, fuel, oil and lubricant, among others (Berger et al., 2003). The use of decision support systems is fundamental to improve operational efficiency and help ensure the success of forest enterprises. In addition, forest planning helps to ensure a more efficient wood supply chain for products including bleached Eucalyptus pulp, capable of adapting to the adverse conditions of the macroeconomic environment while reducing unnecessary risks during production.

In a forest planning context, the allocation of resource and management activities over time, to achieve a specific goal (environmental, financial, volumetric), is possibly the largest problem in forest optimization (Kaya et al., 2016). Several studies have solved forest allocation problems, such as transportation planning (Frisk et al., 2010), harvest area selection and wood allocation to mills (Ouhimmou et al., 2015), optimal allocation of woodchips from forest residues to terminals and power plants (Marques et al., 2018), and optimal allocation of woodchips and logs from thinning and clearcuts (Sosa et al., 2015). Despite these several forest resources allocation studies, there is a lack of studies that address the allocation of forest outgrower scheme areas for wood supplies. There are also few studies considering resource optimization with outgrower schemes in Brazil as observed in Rode et al., (2014) and Rode et al., (2016). This work intents to provide a proactive proposal for the allocation of outgrower schemes, in which the company seeks out rural producers in the most economically attractive regions for forest production.

The objective of the study was to determine the most effective allocation of areas where the outgrower scheme can be implemented including the production cost for an Eucalyptus pulp company. The optimal allocation of these areas is essential to ensure the company's competitiveness in the world pulp market in the face of the current economic crisis in Brazil and possible climatic changes. Finally, based on a sensitivity analysis, we generated thematic maps for contract negotiation that included different transportation systems.

Revista Árvore 2019;43(5):e430504 


\section{MATERIAL AND METHODS}

\subsection{Study area and distribution of the forest outgrower scheme}

The study was conducted in the former Fibria (now Suzano SA), in the Aracruz production unit. This area is distributed across the Brazilian states of Espírito Santo, southern Bahia, and northeastern Minas Gerais, encompassing 117 regions (Figure 1) covering 583,255 ha with rural properties appropriate for forest implantation. Each region is the aggregation of sites with similar characteristics such as forest production and operational costs (e.g. planting and maintenance, harvest, and transportation).

Today the company has contracts in regions that are not financially viable that were implemented without strategic planning, which increases the risk of the business. The focus now is to move new contracts to other regions considering the existing

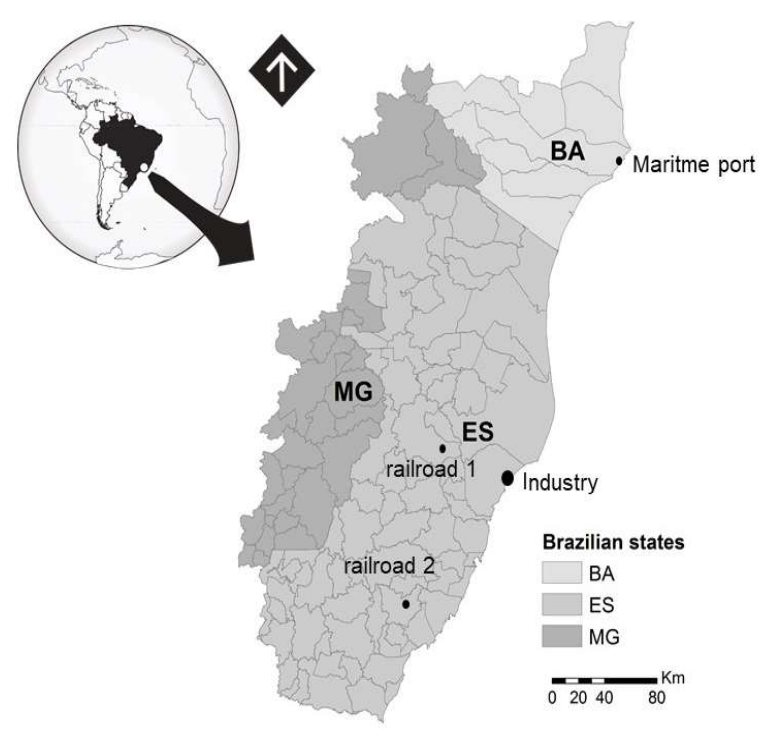

Figure 1 - Spatial distribution of 117 potential regions, located in three Brazilian states: Bahia (BA), Espírito Santo (ES) and Minas Gerais (MG). Location of pulp industry, maritime port (maritime warehouse) and two railroad stations (railroad warehouses)

Figura 1 - Distribuição espacial de 117 regiões potenciais, localizadas em três estados brasileiros: Bahia (BA), Espírito Santo (ES) e Minas Gerais (MG). Localização da indústria de celulose, porto marítimo (depósito marítimo) e duas estaçôes ferroviárias (depósitos ferroviários). road network, transportation distance, topography, level of mechanization, degree of utilization, expected productivity, and proximity to forest stands belonging to Fibria. The selected contract modality by Fibria was the forest outgrower scheme to increase wood production and help regulate the wood supply to the mill. This contract modality is widely used to create social benefits and revenue distribution, because companies provide extra income for small and mediumsized farmers. Fibria's strategy of establishing new outgrower contracts was planned for the years 2016 to 2021, with wood production expected from 2022 to 2027 . Potential regions to establish new outgrower contracts are those within Aracruz production unit.

\subsection{Mathematical modeling}

A mathematical model was developed to determine the amount of area in each region in which to establish the outgrower schemes while reducing the cost of wood production and considering target wood production levels from a 6-year tactical planning level. Restrictions to represent the maximum storage capacity $\left(\mathrm{m}^{3}\right)$ of wood by warehouse were also included in the problem formulation.

The objective function (Eq. 1) is set to minimize the total wood production cost $(Z)$ of achieving the target production level where; $\mathrm{X}_{i j k}$ is the area (ha) to be contracted to outgrowers in region ${ }_{i}$ during year ${ }_{j}$, using the transportation system ${ }_{k}$ after harvest, and $\mathrm{C}_{i j k}$ is the wood production cost (USD/ha) by contracting outgrowers in region ${ }_{i}$, during contract establishment year ${ }_{j}$, using the transportation system ${ }_{k}$. Costs were discounted to year zero (2016) considering an annual interest rate of $8 \%$. I is the total number of regions, ${ }_{J}$ is the total number of years in the tactical planning period (6 years), and ${ }_{K}$ is the total number of transportation systems.

MIN Z $=\sum_{i}^{I} \sum_{j}^{J} \sum_{k}^{K \in i} C_{i j k} X_{i j k}$

Planting and maintenance costs considered fertilizers, herbicides, ant control, seedlings, technical assistance, environmental licensing, soil analysis, quality control and financial advances to the landowners (resources for planting and forest management operations) totaling 1,396.11 USD/ha per year. State taxes were also included in the total cost of wood production; $0.16 \mathrm{USD} / \mathrm{m}^{3}$ in the state 
of Espírito Santo, 0.22 USD $/ \mathrm{m}^{3}$ in Minas Gerais, and zero in Bahia where these taxes are not collected. The cost of purchasing tree grower's wood was based on the value currently paid by Fibria. Transportation cost for each region was calculated based on the freight table that consider the logistical costs to the company (e.g. diesel, loading of wood, highway toll, freight cost) estimated for different distance ranges.

The types of wood transportation systems used by the company are described below: A) Direct Road Transport (DRT): Employed truck1 (35 ton) or truck2 (48 ton), with the cost calculated based on the shortest distance route from the centroid of the regions to the mill. Centroids were located and distances to mills were calculated using a geographic information system. B) Transhipment Road Transport (TRT): Applied only to sloping areas (above $24^{\circ}$ ), where the cost is calculated considering the transhipment to a warehouse and later transport to the mill by truck1 ( 35 ton) or truck2 (48 ton). The shortest distance route from the centroid of the regions to the warehouse and from the warehouse to the mills were considered. C) Road and Rail Transport 1 (RRT1): Reconciled use of highways and railroads, where wood is transported first by truck to a railway warehouse and then via railroad 1 to the mill. D) Road and Rail Transport 2 (RRT2): Reconciled use of highways and railroads, where wood is transported first by truck to a railway warehouse and then via railroad 2 to the mill. E) Road and Maritime Transport (RMT): Reconciled use of highways and a port, where wood is transported first to a maritime warehouse and then via barge to the mill.

Harvesting costs were obtained from company estimates based on three terrain slope classes (A, $\mathrm{B}$, and C) and five site productivity classes. Terrain slope class $\mathrm{A}$ are areas with slope between $0^{\circ}$ and $24^{\circ}$ harvested with tracked harvesters and forwarders. Class B are areas with sloped from $24^{\circ}$ to $35^{\circ}$ harvested with assisted harvesters and wheeled forwarders, each anchored to two trees. Class $\mathrm{C}$ are areas with declivity greater than $35^{\circ}$ harvested manually with chainsaw and winched. The volumetric yield at the time of harvest was predicted based on the average site index of the regions, supported by forecasts involving growth and yields models as well as inferences from specialists from various operational sectors of the company.
Some municipalities in the state of Espírito Santo have local laws that prohibit or restrict planting eucalyptus. The reasons are particular to each municipality, but the general aim of these restrictions is associated with maintaining the diversity of agricultural and forest plantations. This prevents a single crop being predominant in the municipality and reduces environmental and economic risks. After considering all these restrictions, the net area for planting was 326,832 ha in the state of Espírito Santo, 106,917 ha in the state of Bahia, and 149,506 ha in Minas Gerais, which are distributed across the 117 regions.

The equation set (2) limits the area available for planting $\left(A_{i m}\right)$ corresponding to the net area (ha) by slope classification $(\mathrm{m}=1$ : flat area, $\mathrm{m}=2$ : sloping area) in each region $i$, during period $j$, independent of the transportation system $k$ adopted.

$\sum_{\mathrm{j}}^{\mathrm{J}} \sum_{\mathrm{k}}^{\mathrm{K} \in \mathrm{i}} \mathrm{X}_{\mathrm{ijk}} \leq \sum_{\mathrm{m}}^{\mathrm{M} \in \mathrm{i}} \mathrm{A}_{\mathrm{im}} ; \forall_{\mathrm{i}}$

The formulation also included restrictions for future wood demand (Eqs. 3-4), in which Minas Gerais and Espírito Santo (Eq. 3) were separated from the state of Bahia (Eq. 4) because production cost in this latter state is more expensive, but necessary for the regulation purposes. The maritime transportation system is located in the Bahia state and transports wood to the factory in the Espírito Santo state. This transportation system needs to be used for security reasons. The goal is to reduce the flow of trucks on the highway connecting the two states.

In these equations, $v_{i j k}$ correspond to the estimated future productivity $\left(\mathrm{m}^{3} \cdot \mathrm{ha}^{-1}\right)$ in region $i$, during year $j$, and transported by the $k$ system. $V_{m g}$ (Minas Gerais), $V_{e s}$ (Espírito Santo) and $V_{\text {bahia }}$ (Bahia) are the future volumetric demand for wood after the contracting years $j$.

$$
\begin{aligned}
& \sum_{i}^{I K i} \sum_{k}^{\in} v_{i(j+6) k} X_{i j k} \geq V_{m g(j+6)}+V_{e s(j+6)} ; \forall_{j} \\
& \sum_{i}^{I \in B A} \sum_{k}^{K \in i} v_{i(j+6) k} X_{i j k} \geq V_{\text {bahia }(j+6)} ; \forall_{j}
\end{aligned}
$$

Maximum wood storage for the RRT1, RRT2 and RMT transportation systems were also formulated using Eq 5, which considered an annual capacity of $300,000 \mathrm{~m}^{3}, 200,000 \mathrm{~m}^{3}$ and $2,300,000 \mathrm{~m}^{3}$, respectively. 


$$
\sum_{i}^{I} v_{i(j+6) k} X_{i j k} \leq L_{D(j+6)} ; \forall \forall_{j} ; \forall_{k \in D}
$$

where, $L_{d}$ is the maximum storage capacity of the warehouses $D$, with $D=\{$ RRT1, RRT2 and RMT $\}$ in year $j$.

To guarantee the needed technical assistance to tree growers and to avoid exceeding the maximum capacity of service with the available labor, the amount of area contracted to outgrowers is limited each year (Eq.6) where $C M_{i j}$ is the maximum contracting capacity (ha) per year ${ }_{j}$ in region ${ }_{i}$.

$$
\sum_{K=i}^{K} X_{i j k} \leq C M_{i j} ; \forall_{i} ; \forall_{j}
$$

After defining the mathematical model, six scenarios were established. Scenario 1 was the baseline scenario which only allowed establishing outgrower contacts in the states of Minas Gerais and Espírito Santo because of the lower wood production costs (Eqs. 1 and 3). Scenario 2 evaluated which regions are attractive to establish contracts restricting the contracting capacity to regions in compliance with environmental and organic laws (Eqs. 1, 2 and 3). Scenario 3 was similar to Scenario 2 but only considered the state of Bahia (Eqs. 1, 2 and 4). Scenario 4 evaluated the impact of the RMT transportation system on the total wood production cost (Eqs. 1, 2, 4 and 5 where $D=\{$ RMT $\}$ ). Scenario 5 evaluated the impact of the RRT1, RRT2 and RMT systems on the total wood production cost (Eqs. 1, 2, 4 and 5 where D $=\{$ RRT1, RRT2 and RMT $\}$ ). Finally, Scenario 6 evaluated how the constraint of technical assistance influenced the cost of wood production (Eqs. 1, 2, 4, 5 where $D=\{$ RRT1, RRT2 and RMT \} and 6).

The formulations representing the six scenarios were run and solved using the Lindo software 15.0 academic version on a personal desktop computer with an Intel ${ }^{\circledR}$ Core ${ }^{\mathrm{TM}}$ i-5-5200U CPU $2.20 \mathrm{GHz}$ processor and $8 \mathrm{~GB}$ of RAM. Scenario solutions were compared based on the objective function value (wood production cost $\mathrm{UDS} / \mathrm{m}^{3}$ ) as well as the average transportation distance from each region to the destination.

The scenario closest to the company's longterm planning, which includes meeting volumetric goals and the largest number of restrictions, due to implementation feasibility, was selected as the best scenario. For this best scenario, a sensitivity analysis was conducted using the concept of reduced cost, which are widely used for economic decisionmaking in many areas of study. The reduced cost of a variable can be interpreted as the amount the objective function coefficient of the variable must improve before the variable enters the solution. This interpretation was presented in a study by Mohammadi et al. (2016) with a case for planting forest species. For the present study, this concept quantifies the intensity of the improvement in the cost to purchase tree grower's wood in each region taking into account the associated transportation system, so that it can be viable for the outgrower scheme. A map of wood purchase cost reduction per region was generated to understand the spatial relationships, transportation systems and productivity in the wood supply. The percentage reduction rate $(t x)$ was calculated using equation (7), where $c_{i j k}$ is the total wood production cost in region $i$, during contracting year $j$, using the transportation system $k$ for wood after harvest; and $r d_{c i j k}$ indicates the reduced cost of the respective decision variable $X_{i j k}$.

$$
t x(\%)=\left(c_{i j k}-r d c_{i j k} / c_{i j k}\right) * 100
$$

\section{RESULTS}

\subsection{Behavior of the economic scenarios and the cost of wood}

The mean solution time among the six scenarios was $0.5 \mathrm{~s}$. The nature of the continuous decision variable generated a gain in processing time via the simplex algorithm by the solver. This rapid solution time shows the flexibility of the model, which can be used by companies to efficiently create and evaluate different scenarios for decision-making.

The total wood production cost over the 6-year planning horizon was the smallest for Scenario 1 (32.43 $\mathrm{USD} / \mathrm{m}^{3}$ ) and increased almost constantly (to 41.56 $\mathrm{USD} / \mathrm{m}^{3}$ ) for the remaining scenarios (Table 1). Scenario 1 did not consider the constraint of the effective area of planting by region nor the limitations in the use of transportation systems, only the requisite of wood to supply the mill. The type of transportation system had an influence on the total cost of wood because the road system presented the lowest cost, due to the smaller average radius of displacement of $45 \mathrm{~km}$, 
Table 1 - Spatial and economic aspects for the six scenarios available.

Tabela 1 - Aspectos espaciais e econômicos para os seis cenários disponíveis.

\begin{tabular}{|c|c|c|c|c|c|c|c|c|}
\hline \multirow{3}{*}{ Scenario } & \multicolumn{3}{|c|}{ Spatial aspects* } & \multicolumn{3}{|c|}{ Economic aspects } & & \\
\hline & \multirow[t]{2}{*}{$\begin{array}{l}\text { OSA } \\
\text { (ha) }\end{array}$} & \multirow[t]{2}{*}{$\begin{array}{c}\mathrm{NZ} \\
(\mathrm{km})\end{array}$} & \multirow[t]{2}{*}{$\overline{\mathrm{AD}}$} & \multicolumn{2}{|c|}{ Total cost of wood } & \multicolumn{3}{|c|}{ Cost of wood by activity } \\
\hline & & & & Thousand USD & $\mathrm{USD} / \mathrm{m}^{3}$ & Harvest & Transportation & Others \\
\hline 1 & 63,270 & 1 & 45 & 235,689 & 32.43 & $26 \%$ & $14 \%$ & $61 \%$ \\
\hline 2 & 70,509 & 29 & 111 & 262,447 & 36.35 & $24 \%$ & $21 \%$ & $55 \%$ \\
\hline 3 & 71,535 & 20 & 142 & 270,018 & 37.28 & $24 \%$ & $23 \%$ & $53 \%$ \\
\hline 4 & 69,390 & 21 & 160 & 290,075 & 39.95 & $22 \%$ & $28 \%$ & $50 \%$ \\
\hline 5 & 67,318 & 22 & 161 & 301,053 & 41.48 & $21 \%$ & $31 \%$ & $48 \%$ \\
\hline 6 & 67,395 & 24 & 163 & 302,008 & 41.56 & $21 \%$ & $31 \%$ & $48 \%$ \\
\hline
\end{tabular}

*OSA: área de fomento florestal; NZ: número de regióes; AD: distância média.

compared to $163 \mathrm{~km}$ of multimodal radius in Scenario 6 (Table 1). As a result, the share of transportation costs increased from $14 \%$ for Scenario 1 to $31 \%$ for Scenario 6 (Table 1).

When constraints to limit the planting area per region were introduced in Scenario 2, a larger number of regions were selected for planting, 29 regions (Table 1). Consequently, there was an 11 $\%$ increase in the outgrower scheme area from 63,270 to $70,509 \mathrm{ha}$, and a $12 \%$ increase in the cost of wood from 32.43 to $36.53 \mathrm{USD} / \mathrm{m}^{3}$ (Table 1). We also highlighted the variation of transportation cost between Scenario 1 and Scenario 2, from 14\% to $21 \%$. As expected, Scenario 2 and 3 showed similar results. The introduction of state of Bahia on the model produced an additional increase of only $1 \%(70,509$ to $71,535 \mathrm{ha})$ for the outgrower scheme area and $3 \%$ (36.35 to $37.28 \mathrm{USD} / \mathrm{m}^{3}$ ) for the cost of wood (Table 1). The increase in transportation cost was $2 \%$ (from 21 to $23 \%$ ), which is acceptable because the areas available for planting in the state of Bahia are further away from the factory.

Table 2 - Reduction in the wood purchase cost that allows the activation of new regions under Scenario 6.

Tabela 2 - Redução no custo de compra da madeira que permite a ativação de novas regiões no cenário 6 .

\begin{tabular}{lccccc}
\hline $\begin{array}{l}\text { Reduction in the total wood purchase cost (\%) } \\
\begin{array}{l}\text { Region } \\
\text { Number }\end{array}\end{array}$ & \multicolumn{5}{c}{ Transport system type } \\
\cline { 2 - 6 } & DRT & TRT & RRT1 & RRT2 & RMT \\
\hline 2 & 18 & 94 & 9 & - & - \\
\hline 36 & 3 & 49 & - & - & - \\
\hline 46 & 60 & 149 & - & - & - \\
\hline 114 & & & & & - \\
\hline
\end{tabular}

Revista Árvore 2019;43(5):e430504
The other scenarios activated other transportation systems at some point during the 6-year planning. The activation of the RMT system in Scenario 4 was required to meet the demand from regions located in the state of Bahia and near the maritime warehouse. This increased the cost of wood production by $7 \%$ (37.28 to $39.95 \mathrm{USD} / \mathrm{m}^{3}$ ) (Table 1), with transportation costs accounting for $5 \%$ (23\% to $28 \%)$ of this increase. The average cost of wood production and the average distance followed the same trend observed because they present a high correlation.

The activation of all transportation systems in Scenario 5 caused an additional increase in the cost of wood of $4 \%$ (39.95 to $41.48 \mathrm{USD} / \mathrm{m}^{3}$ ), with transportation costs accounting for $3 \%$ (28\% to $31 \%)$ of this increase. Scenario 6 resulted in a slight increase in the cost of wood by $0.2 \%$ (41.48 to $\left.41.56 \mathrm{USD} / \mathrm{m}^{3}\right)$. Although providing the largest cost, Scenario 6 showed better operational feasibility because 24 regions with diversified wood transport were activated; the DRT, RRT1, RRT2 and RMT systems.

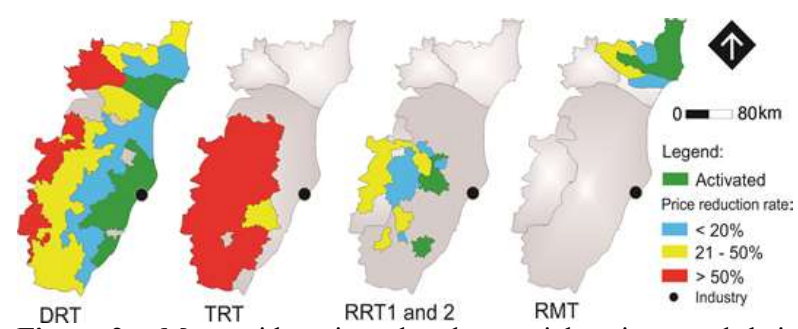

Figure 2 - Maps with activated and potential regions, and their respective reduction rates in the wood purchase cost (Scenario 6).

Figura 2 - Mapa com regiões ativadas e potenciais, e suas respectivas taxas de redução no custo de compra da madeira. 
Table 3 - Summary of comparison between the tactical planning scenarios for initiating/renewing the outgrower scheme and that predicted by the company in the only first year.

Tabela 3 - Resumo da comparação entre os cenários do planejamento tático para contratar/renovar fomentos florestais e aquele previsto pela empresa somente para

\begin{tabular}{|c|c|c|c|c|}
\hline Scenario & $\begin{array}{l}\text { Total cost } \\
\text { (USD) }\end{array}$ & $\begin{array}{c}\text { Cost } \\
\text { reduction } \\
(\%) \\
\end{array}$ & $\begin{array}{c}\text { Cost of } \\
\text { wood } \\
\text { USD } / \$ . \mathrm{m}^{-3} \text { ) }\end{array}$ & $\begin{array}{c}\text { Mean } \\
\text { distance } \\
(\mathrm{km})\end{array}$ \\
\hline Empirical & $138,972,844$ & - & 44.44 & 205 \\
\hline 1 & $101,415,759$ & -27.0 & 32.43 & 45 \\
\hline 2 & $103,123,283$ & -25.8 & 32.98 & 62 \\
\hline 3 & $110,542,822$ & -20.5 & 35.35 & 111 \\
\hline 4 & $119,096,281$ & -14.3 & 38.09 & 131 \\
\hline 5 & $124,704,421$ & -10.3 & 39.88 & 140 \\
\hline 6 & $126,163,989$ & -9.2 & 40.35 & 149 \\
\hline
\end{tabular}

3.2 Analysis of sensitivity and variation in the wood purchase cost

An alternative to increasing the number of regions in which to establish outgrower schemes is to reduce the associated wood purchase cost. When considering the most realistic scenario 6 , we can see the existence of potential regions for the outgrower scheme (Table 2). The potential regions to be activated indicate a minimum reduction in the wood purchase cost, while for the non-potential regions, the reduction rate reaches unviable values close to $100 \%$. This change in cost still allows changes in the types of active transportation systems .

Considering scenario 6, Figure 2 shows the relationship between the reduction rates in the wood purchase cost in the different regions by transport system adopted.

The forecast for initiating/renewing outgrower contracts based on the experiences of technicians (empirical scenario) for the first year was compared with the forecast generated by the model in Scenario 6 (Table 3). In the empirical scenario, there are 48 regions activated. This large number of regions hinders the company's efficiency directly reflected by the increase in the radius of operation from $163 \mathrm{~km}$ to 205 $\mathrm{km}$. The empirical scenario hinders the allocation of teams during the initiating/renewing of the outgrower scheme also affecting the logistics of providing technical assistance. By contrast, scenario 6 allows for a more feasible implementation by concentrating contracts on only 24 regions. The spatial distribution of the regions was concentrated around the mill, forming homogeneous blocks to initiate/renew outgrower contracts, which also reduced wood production cost by $9.2 \%$ and the average transportation displacement by $56 \mathrm{~km}$ (Table 3 ).

\section{DISCUSSION}

\subsection{Cost of wood and transportation systems}

Compared with Scenario 1, Scenarios 2 and 3 showed a larger number of regions for initiating/ renewing the outgrower contracts selecting the DRT system for the transportation of wood to the mill (Table 1). This demonstrated the greater economic attractiveness of the DRT (Road) compared with RRT (Rail) and RMT (Maritime). By contrast, recent studies on maritime transportation indicate a highly competitive position of this transport modality compared with other transportation systems. On average in Brazil, freight is $40 \%$ cheaper than road transportation for similar distances (Nascimento, 2012). Our results were contradictory due to the high fixed (structural) cost of the RMT system, which is responsible for the high cost of this transport system compared to the DRT system. The competitiveness of this transport system could be facilitated by the expansion of the number of barges and an increase in the volume of wood, which would dilute the fixed cost and consequently reducing the transportation cost per $\mathrm{m}^{3}$. Also, the maritime system has other advantages when compared to the road system such as reduced pollution, greater safety and load capacity (Caxito, 2011).

To make the RRT1 and RRT2 systems economically viable, a $23 \%$ reduction in the wood cost would be required, and for the RMT the reduction is even higher at $36 \%$ considering Scenario 3. Rail transport is the second-most utilized system in the flow of cargo transported in Brazil, while road transport accounts for more than 50\% (Alves et al., 2013). According to Machado et al. (2009), in Brazil, forest transportation is mainly carried out by the road system due to history and national trends. Other contributing factors are the extensive road network, the availability of different types of vehicles and a low installation value when compared to other existing transportation systems .

Results show a direct relationship between average transportation distance and wood cost (Table 1), which is expected because larger distances cause higher transportation costs (Ghaffariyan et 
al., 2013). According to Börjesson and Gustavsson (1996), truck transportation is more efficient for relatively shorter distances, and trains and barges are more efficient for longer distances. Therefore, the transportation cost could be reduced for longer distances if a change from road to rail or waterway is conducted (Börjesson and Gustavsson, 1996). In the analyzed scenarios, transportation cost reached $31 \%$ of the total cost, which is relatively high for a single operation (Table 1). This large cost share confirms the importance of analyzing and planning the operational alternatives in the transport of wood.

The strategies for initiating forestry outgrower schemes are essential to guarantee the wood supply to the pulp mills in Brazil. Studies indicate that the economic returns of tree grower projects are higher than those from commercial plantations carried out exclusively by the forestry company (Rode et al., 2015; Rode et al., 2016). Rezende et al. (2006) and Rode et al. (2015) simulated different scenarios by testing the feasibility of forest plantations and confirmed that the purchase of standing timber was more attractive when compared to other forms of wood procurement because of the reduction in the cost of wood production, which validates the logic of timber purchase in the present study. We have highlighted the importance of evaluating several scenarios for decision making at large-scale companies, such as the one considered in the present study.

\subsection{Reduced cost}

The reduction rates proposed in Table 2 are drivers for investment in operational development to increase the efficiency in the indicated regions. The expansion of the transportation capacity and planting mechanization are some examples of improvements by the company. After studying and exhausting the possibilities of operational improvements, the second alternative would be to negotiate wood purchase cost with suppliers and tree growers.

Four regions with contracting potential can be activated and introduced into the result if there is a reduction in the wood purchase cost. This reduction could be achieved by negotiating for lower tariffs with suppliers or to increase transportation capacity. For example, Region 2 requires a reduction of only $5 \%$ in the cost of wood to be activated via the RMT system. This reduction can be realized with the expansion in the number of barges and the consequent increase of transported volume and dilution of fixed costs. We have highlighted that $5 \%$ reduction activates only a particular transport system but may become impracticable for another system, even with a reduction in the wood purchase cost.

Region 114 is economically infeasible for the expansion of the forestry outgrower scheme because its areas are distant and inclined. The use of the TRT transport system requires a $149 \%$ reduction rate in the wood purchase cost, and $60 \%$ considering the DRT system. Working in this type of region with high operating costs is not advisable. For the expected profits to occur, it will be necessary to apply high reductions in the amount paid to the tree growers, making the business impractical. By contrast, in region 2, negotiation between the company and the tree grower is viable because if wood purchase is reduced by only 5\%, considering the RMT system for transportation of wood, the region becomes attractive to the company. By contrast, in region 46 , a $3 \%$ reduction in the price of wood is required because this region has a flat area and is closer to the mill. The distance is only $128 \mathrm{~km}$, that is, $35 \mathrm{~km}$ less than the average transport distance of Scenario 6. According to Rode et al. (2014), the outgrower net present value for Eucalyptus forests in the state of Minas Gerais depends on the incentives, wood price, distance and production, which corroborates our results.

By analyzing the TRT transport map, we confirm that it is the least suitable for transporting wood (Figure 2). The activation of regions using this system requires a reduction of more than $50 \%$ in the wood purchase cost. Nonetheless, due to the greater range in the use of the DRT system and the ease of roads connecting mill and rural producer, this presents clear regions of well-defined prices. The RMT system only occurs in the northern region of the area available for the outgrower scheme but it is restricted to a small number of regions.

\section{CONCLUSIONS}

In Brazilian pulp companies, wood originated from partnerships with rural producers represents a large part of the industrial supply. In this study, with the use of a single optimization model and activating different constraints, it was possible to evaluate

Revista Árvore 2019;43(5):e430504 
scenarios for the allocation of Eucalyptus stands with the outgrower scheme in economically efficient areas. In addition, we developed thematic maps for the negotiation of new contracts that included different transportation systems. We highlight the importance of developing this model due to two main factors that make complex this allocation problem of outgrower scheme. The first factor is the extensive area available for Eucalyptus cultivation, in three Brazilian states with different governmental laws, operational costs and productivities. Secondly, the possibility of using three of wood transportation systems. In summary, the use a decision support system in this work is relevant for improving the efficiency of forest planning and helping to ensure the success of partnerships.

Six scenarios were solved to simulate strategies of allocation of outgrower schemes according to the operational possibilities existing in the area of study. From Scenario 1 to 6 , new constrains and transportation systems were added with the goal of understanding the impact of each scenario on the total wood production cost. As expected, wood production cost was smallest for Scenario $1\left(32.43 \mathrm{USD} / \mathrm{m}^{3}\right)$ and increased almost constantly (to $41.56 \mathrm{USD} / \mathrm{m}^{3}$ ) for the remaining Scenarios from 2 to 6 . The activation of all transportation systems occurred under Scenario 5. In Scenario 6, 24 regions and 4 transportation systems (DRT, RRT1, RRT2 and RMT) were activated. The benefit of the formulated model was the very quick solution time, because it can help with efficiently evaluating different alternative to facilitate decision making.

The developed model allows the company to update its forest expansion strategies periodically, according to variations in factors such as the demand for wood, variation in operating costs, availability of new areas, and changes in municipal laws. Furthermore, mitigation of contract breach becomes more likely since decisions are made based on an optimization model and no longer empirically.

Briefly, among several applications of this model for the company, we can highlight the possibility of use for the allocation of lease agreements (land leasing), another form of partnership existing in the company. Additionally, the development of a stochastic model that considers the uncertainties of input variables of the model to support decision making under risk conditions was identified as a good approach for future work on the allocation outgrower schemes.

\section{REFERENCES}

Alves RT, Fiedler NC, Silva EN, Lopes ES, Carmo FCA. Análise técnica e de custos do transporte de madeira com diferentes composições veículares. Revista Árvore. 2013;37(5):897-904.

Berger R, Timofeiczyk Junior R, Carnieri C, Lacowicz PG, Sawinski Junior J, Brasil AA. Minimização de custos de transporte florestal com a utilização da programação linear. Revista Floresta. 2003;33(1):53-62.

Börjesson P, Gustavsson L. Regional production and utilization of biomass in Sweden. Energy. 1996;21(9):747-764

Caxito F. Logística: um enfoque prático. Second. São Paulo: Saraiva; 2011.

Fibria celulose. [acessado em: 01 de fev. de 2016] Disponível em: http://www.fibria.com.br/quem-somos/

Fischer A, Zylbersztajn D. O fomento florestal como alternativa de suprimento de matéria-prima na indústria brasileira de celulose. Revista Eletrônica de Administração. 2012;18(2):494-520.

Frisk M, Göthe-Lundgren M, Jörnsten K, Rönnqvist M. Cost allocation in collaborative forest transportation. European Journal of Operational Research. 2010;205(2):448-458.

Ghaffariyan MR, Acuna M, Brown M. Analysing the effect of five operational factors on forest residue supply chain costs: a case study in Western Australia. Biomass and Bioenergy. 2013;59:486-493.

Kaya A, Bettinger P, Boston K, Akbulut R, Ucar Z, Siry J, et al. Optimisation in Forest Management. Current Forestry Reports. 2016;2(1):1-17.

Machado CC, Lopes ES, Birro MH. Elementos básicos do transporte florestal rodoviário. Viçosa: UFV; 2009. v.2

Marques A, Rasinmäki J, Soares R, Amorim P. Planning woody biomass supply in hot systems under variable chips energy content. Biomass and Bioenergy. 2018;108:265-277.

\section{Revista Árvore 2019;43(5):e430504}


Mohammadi Z, Limaei SM, Shahraji, TR. Linear programming approach for optimal forest plantation. Journal of Forest Research. 2016;28(2):1-9.

Nascimento MV. Proteção e liberalização no transporte marítimo de cabotagem: o uso da regulação nos mercados canadense e brasileiro. Journal of Transport Literature. 2012;6(4):228-234.

Oliveira PRS, Valverde SR, Coelho FMG. Aspectos de relevância econômica no fomento florestal a partir da percepção dos produtores rurais envolvidos. Revista Arvore. 2006;30(4):593-602.

Ouhimmou M, Haddad S, Boukherroub T. Decision support system for selection of harvest areas and wood allocation to mills. IFAC-PapersOnLine. 2015;48(3):628-633.

Rezende JLP, Padua CTJ, Oliveira AD, Scolforo JRS. Análise econômica de fomento florestal com eucalipto no Estado de Minas Gerais. Revista Cerne. 2006;12(3):221-231.

Rode R, Leite, HG, Silva ML, Ribeiro CAAS, Binoti DHB. The economics and optimal management regimes of eucalyptus plantations: a case study of forestry outgrower schemes in Brazil. Forest Policy and Economics. 2014;44:26-33.

Rode R, Leite HG, Oliveira MLR, Binoti DHB, Ribeiro CAAS, Souza AL, et al. Comparação da regulação florestal de projetos de fomento com áreas próprias de empresas florestais. Pesquisa Florestal Brasileira. 2015;35(81):11-19.

Rode R, Leite HG, Binoti DHB, Ribeiro CAAS, Souza AL, Cosenza DN, et al. Applying classical forest regulation methods to smallholdings with cooperative constraints. Revista Cerne. 2016;22(2):197-206.

Silva FL, Griffith JJ, Jacovine LAG, Valadares JH, Fernandes MAS, Silva ECG. Estudo da relação de confiança em programa de fomento florestal de indústria de celulose na visão dos produtores rurais. Revista Árvore. 2009;33(4):723-732.

Sosa A, Acuna M, McDonnell K, Devlin G. Managing the moisture content of wood biomass for the optimisation of Ireland's transport supply strategy to bioenergy markets and competing industries. Energy. 2015;86:354-368. 